\title{
Climate Change and Cities: Challenges Ahead
}

\author{
Prashant Kumar ${ }^{1,2 *}$ \\ ${ }^{1}$ Global Centre for Clean Air Research (GCARE), Department of Civil and Environmental Engineering, Faculty of Engineering \\ and Physical Sciences, University of Surrey, Guildford, United Kingdom, ${ }^{2}$ Department of Civil, Structural \& Environmental \\ Engineering, Trinity College Dublin, Dublin, Ireland
}

Keywords: climate adaptation, nature-based solutions, environmental pollution, human health, urbanisation

\section{CLIMATE CHANGE, AIR POLLUTION AND CITIES}

Climate change is the most significant threat to life on Earth. It results from natural and anthropogenic emissions of air pollutants, especially greenhouse gases (GHGs), causing large-scale effects on the climate (IPCC, 2013). In other words, the complicated relationship between air pollution and climate change is primarily driven by GHGs (Von Schneidemesser et al., 2015; Xu and Lamarque, 2018). Water vapor, ozone $\left(\mathrm{O}_{3}\right)$, nitrous oxide $\left(\mathrm{N}_{2} \mathrm{O}\right)$, carbon dioxide $\left(\mathrm{CO}_{2}\right)$, and methane $\left(\mathrm{CH}_{4}\right)$ are among the GHGs causing global warming, although the latter two account for $90 \%$ of GHGs and are primarily emitted by the burning of fossil fuels (Kumar and Imam, 2013; EPA, 2020; Kumar et al., 2020a).

As depicted in Figure 1, air pollution and climate change are inextricably linked in terms of (i) emission sources, (ii) climate characteristics and chemistry, and (iii) mitigation measures. They both entail significant consequences for human health. For instance, particulate matter (PM) are not only associated with adverse health impacts (Heal et al., 2012) but also have a circuitous climatic impact, as they can serve as cloud buildup nuclei and thus influence climate forcing as well as meteorological phenomena, e.g., dissipating or capturing inward irradiation (Williams, 2012; Von Schneidemesser et al., 2015; Maione et al., 2016). Likewise, global temperature rise, drought, declining water resources, shrinking ice sheets, flooding and erosion in coastal areas, ocean acidification, rising sea levels, and increasing extreme weather events present irrefutable evidence of global warming (Figure 1). Although these global issues are seen as distinct problems in numerous fields of research and policy, they are inevitably connected, and any alleviation policy in one area could affect circumstances in another (Von Schneidemesser et al., 2015), requiring a holistic approach to solutions.

Global warming makes cities warmer, while urbanisation intensifies this process via urban heat island generation and aerosol radiative forcing. The consequences of interactions among climate change, the urban heat island effect, and air pollution are expected to increase the risk of poor human health in cities globally by the middle of the twenty-first century. Investigation into linkages between climate variables (e.g., temperature, relative humidity, air quality index) and health risks (e.g., mouth, foot and hand disease) revealed that the health impacts of climate change were more substantial in areas of lower air quality (Du et al., 2019). Air pollution affects atmospheric evaporation by increasing the volume of field occurrence irradiation in the climate system, which is the essential force for evaporation (Yao, 2017). In addition, it is suggested that high $\mathrm{PM}_{2.5}$ concentrations in earth's atmosphere may result in inadequate moisture for crop production. Furthermore, hotter metropolitan climates escalate the impacts of air contamination on mortality associated with pneumonia disease. In Hong Kong, the acute mortality effects of pneumonia have been found to increase with warmer weather and be further exacerbated during peak hours of air pollution, indicating that a hotter city climate due to global warming and urbanism may raise the risks of air contamination-pneumonia (e.g., Sun et al., 2019). In short, global warming and urban development are making metropolitan areas warmer and influencing the chemistry of urban air pollution. 


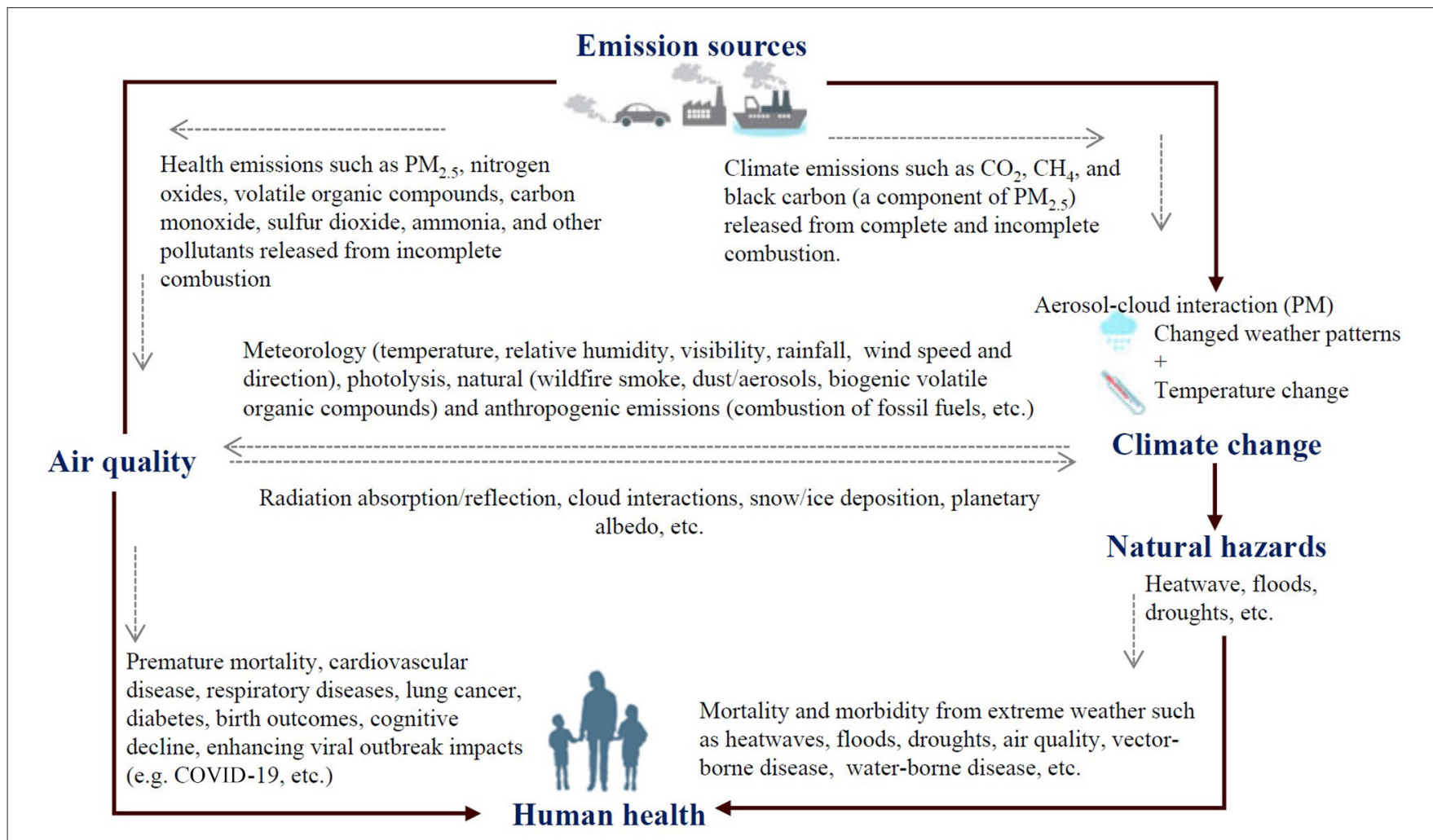

FIGURE 1 | A simple schematic diagram showing the interconnections between air pollution, climate and human health.

Climate change could influence the lifespan, dispersion, and associated health impacts of many different pollutants, including $\mathrm{PM}_{2.5}$ (e.g., $\mathrm{Xu}$ and Lamarque, 2018). Therefore, climate change and air pollution mitigation measures have ramifications for one another. For example, Shindell et al. (2012) highlighted 14 mitigation measures for specific air pollutants, such as black carbon and $\mathrm{CH}_{4}$, which can decrease anticipated global mean temperature by $\sim 0.5^{\circ} \mathrm{C}$ by 2050 and enhance food security and human health simultaneously. A goal-oriented climate change mitigation and adaptation agenda has the potential to both protect our wellbeing and future, and to diminish the yearly seven million deaths from air pollution across the world (Schmale et al., 2014). Shindell et al. (2017) also suggested that decreasing shortlived climate pollutants over the coming 25 years can significantly lower the anticipated $0.5^{\circ} \mathrm{C}$ change in future climate scenarios as a near-term target, as well as offering numerous possible co-benefits in terms of accomplishing Sustainable Development Goals (SDGs).

The contemporary overconsumption of energy is one central cause of GHG emissions and, subsequently, global warming and climate change. Developing a sustainable energy program and effectively managing natural resources are key to tackling this issue. Other important steps include reducing the demand for energy generated from fossil fuels, improving the efficiency of products over the life cycle, reusing and recycling materials where prudent, and switching to cleaner fuels in the transportation sector.

\section{HEALTH AND ENVIRONMENTAL RISKS TO CITIES UNDER A CHANGING CLIMATE}

Global warming will have tremendous ramifications for people's wellbeing, particularly in terms of water- and vector-borne contagious diseases (Shuman, 2010). The routes through which climate change and related variabilities influence human health are connected to different social, natural, biological and economic factors. At the same time, the development, spread, and endurance of pathogens play an important role in disease transmission (Figure 2). Global warming could pose hazards to human health and wellbeing by triggering rises in extreme weather and climate-related events (e.g., droughts, heatwaves, floods) and air pollution (Rahmstorf and Coumou, 2011; Watts et al., 2015). The geography of ecological effects and impacts on the wellbeing of climate change-driven pollutants are inconsistent (Adger, 2006). In particular, urban citizens of low- and average-income nations are most susceptible because of their significant exposures to changing weather conditions and air pollutants, and limited ability to control and adjust to these risks (IPCC, 2014; WHO, 2014; Ma et al., 2020). 


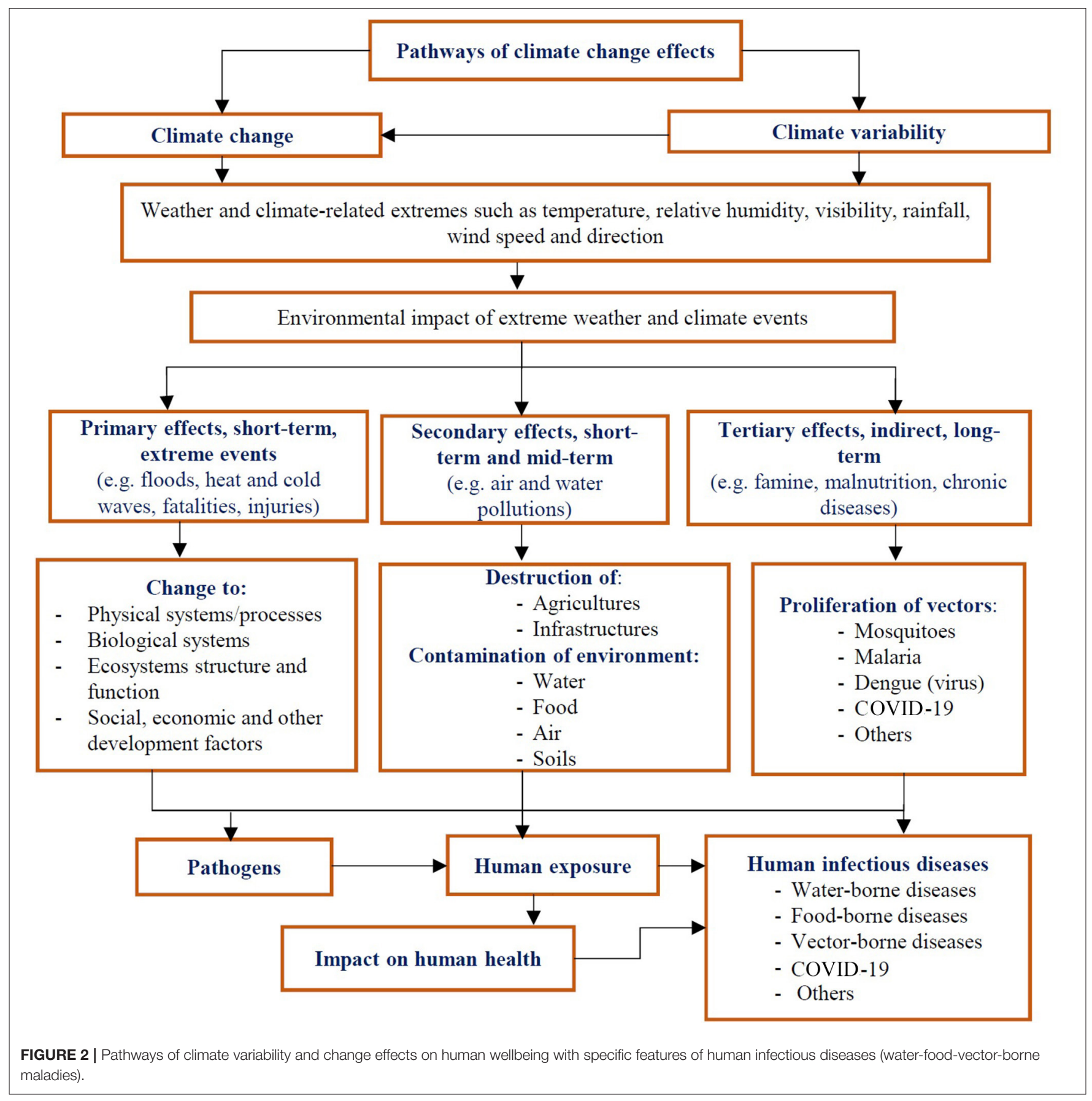

Climate change could also affect human health and deteriorate the surfaces of building materials by amplifying the concentrations of secondary pollutants, such as $\mathrm{O}_{3}$ (Kumar and Imam, 2013; Xu and Lamarque, 2018). Evidence from recent years shows that climate change can be linked with detrimental wellbeing outcomes (Patz et al., 2014). By 2050, many cities around the world might face more recurrent, intense heatwaves during days and nights. Episodes of extreme heat are also strongly linked with days of $\mathrm{O}_{3}$ exceedance. Impacts of extreme climate events on people's wellbeing had not been straightforwardly reported, and furthermore, there is no distinct proof of it. Yet, numerous investigations (Ebi et al., 2006; O’Neill and Ebi, 2009; Shuman, 2010; Masselot et al., 2018) have indicated that human endeavours have steadily affected natural environmental factors throughout the past 50 years. On that note, heatwaves, floods, air contamination, aeroallergens, droughts, and vector-borne infections might be considered as the result of our historical actions, which subsequently trigger excess morbidities and mortalities. Such detrimental health perspectives linked with climate change 


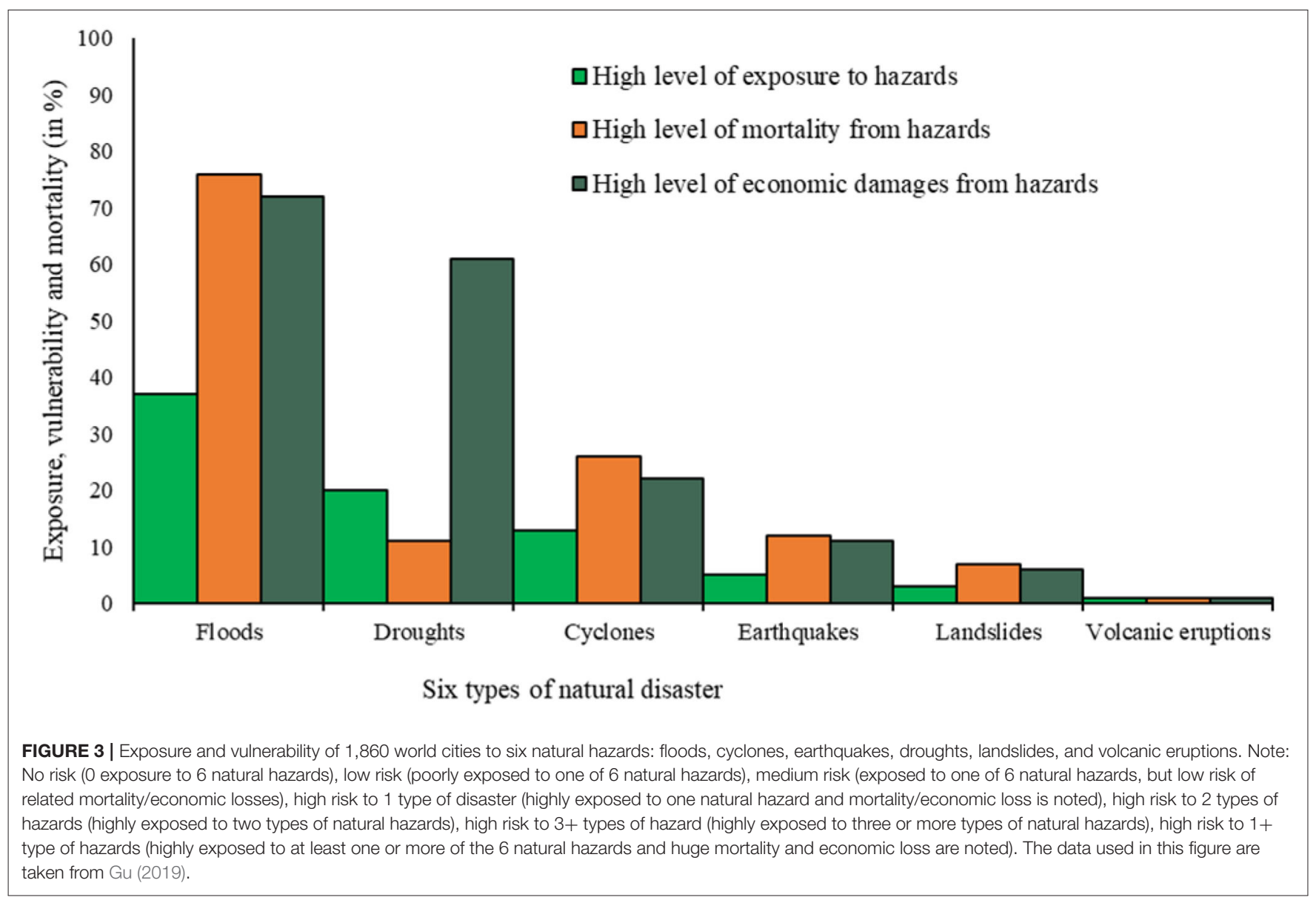

include heat-associated issues, e.g., thermal discomfort (excess cold or heat); decreased work capability; respiratory problems comprising those intensified via air pollutants and aeroallergens, e.g., COVID-19, asthma; irresistible ailments including vectorborne diseases and water-borne maladies, such as childhood gastrointestinal illnesses; food instability and malnutrition, such as due to diminished crop yields; and mental health crises, e.g., post-traumatic stress disorders and other issues related with natural hazards. Significant health and monetary co-advantages could be related to decreased fossil fuel exploitation (Patz et al., 2014). Therefore, climate change mitigation and adaption measures constitute a significant challenge for quite a long time to come. Meanwhile, with the anticipated increase in heatwave occurrence and other weather- and climate-related changes, human wellbeing will be significantly impacted by climate change (Figure 2).

\section{NATURAL HAZARDS AFFECTING CITIES}

Projections related to global warming show an increase in the recurrence and extent of natural disasters that will influence the global community and the environment (EEA, 2017; IPCC, 2018). A natural hazard can cause widespread loss and entail severe changes in the normal functioning of societies at any location due to its interplay with states of coping capacity, vulnerability and exposure, resulting in loss to the economy, human lives and damage to biodiversity (UNISDR, 2020). Hazard intensity is determined by the impact of a disaster on communities, and the scale of effects depends upon the decisions we make for our life and surroundings (UNISDR, 2002). For example, rapid urbanisation under climate change, without efforts to increase resilience, is exposing cities around the globe to enormous risks, and particularly cities built along waterways or near coasts (Kumar and Saroj, 2014; Re Swiss, 2020). For instance, Gu (2019) studied the exposure and vulnerability of 1,860 cities and urban areas to natural disasters (floods, cyclones, earthquakes, droughts, landslides, and volcanic eruptions; Figure 3). The study highlighted that metropolitan planners and decision-maker need to reinforce resilience and adaptation strategies to tackle the increasing impacts of natural hazards and with the target of accomplishing SDGs. Of the studied metropolitan areas, almost 58\% were highly exposed to at least one of the six natural hazards (Figure 3). Moreover, slightly $<14 \%$ and around $2 \%$ of the cities were profoundly exposed to more than two and three natural hazards, respectively (Figure 3).

In general, the majority of the world's riskiest cities are located in East Asia, China, Taiwan, the Philippines and Japan, on the basis of their degree of exposure to natural hazards (Gu, 2019). Many of these metropolitan areas are situated on the coast and are jeopardized by floods, storms, earthquakes 


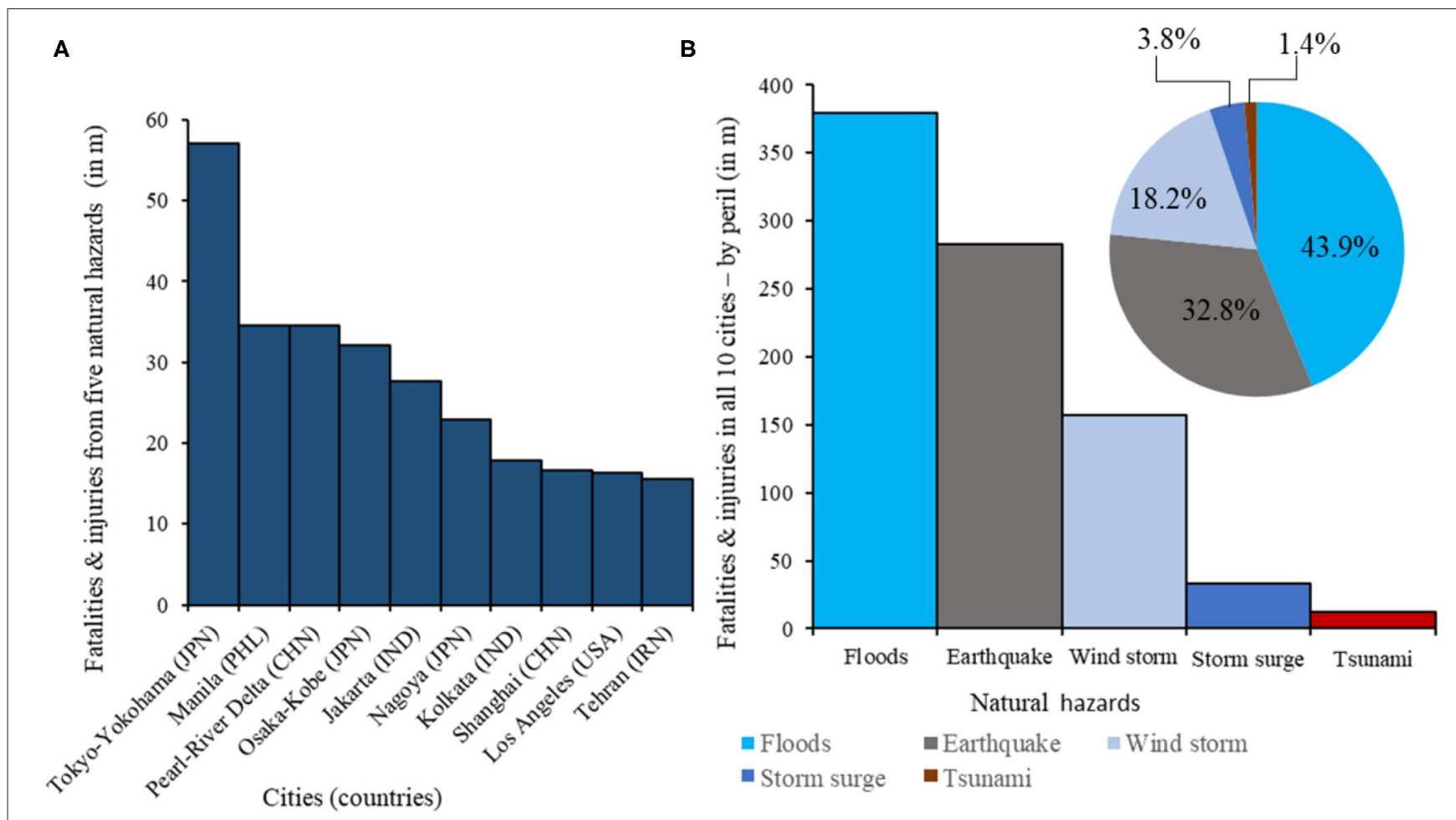

FIGURE 4 | (A) Fatalities and injuries aggregated for all five hazards (in million)-by cities (counties), and (B) cumulative number of fatalities and injuries impacted in all 10 cities areas - by hazards. The data used in this figure are taken from Swiss Re (2020). Acronyms: JPN (Japan), PHL (Philippines), CHN (China), IND (India), USA (United States of America), and IRN (Iran).

and other natural disasters (Figure 3). Figure 4A shows the ten most severely impacted cities by natural hazards across the world. Overall, floods, earthquakes and wind storms caused damage to $43.9,32.8$, and $18.2 \%$ of inhabitants, respectively, while another $5.2 \%$ of inhabitants were potentially devastated by storm surges and tsunamis (Figure 4B). Clearly, the effects of a natural hazard in some densely occupied cities can be catastrophic (Debele et al., 2019). This is why disaster risk planning and management is nowhere more urgent than in the world's large metropolitan areas.

\section{GLOBAL HEALTH AND ECONOMIC BURDEN DUE TO NATURAL HAZARDS}

Challenges associated with climate change, such as droughts, heatwaves, and flooding, are intensified in low-to middle-income countries due to poverty, inadequate development, and high dependence on natural wealth (Rogelj et al., 2016). Figure 3 shows that 83,32 , and $7 \%$ of cities, respectively, were at high risk of natural hazard-related mortality from at least one, two and three out of the six types of natural hazards. Figure 5 shows that $76 \%$ of 1,860 analyzed metropolitan areas were situated in territories profoundly vulnerable to flood-related mortality. Natural hazards not only have a significant impact on human lives and health (Figure 3), but they can also considerably disrupt the local economies of metropolitan areas and, in some cases, entire countries. Figure 3 also shows that $89 \%$ of cities were situated in regions considered highly vulnerable to economic damage from at least one natural hazard. About $72 \%$ of 1,860 metropolitan areas were situated in regions of high exposure and vulnerability to flooding-associated economic damage (Figure 5). Figure 5 also shows the corresponding data for other hazards, and the associated level of exposure, vulnerability, mortality and economic damage. In general, these observations suggest that most of the metropolitan areas were highly exposed to both flood-associated mortality and economic damage (Figure 5).

\section{GRAND CHALLENGES TO FILL EXISTING GAPS FOR HEALTHY CITIES UNDER CLIMATE CHANGE}

Air contamination and climate change are critical issues worldwide, bearing substantial impacts on people's wellbeing and economic growth. In spite of the fact that there are many long-term possibilities to tackle these problems with coordinated policies, the immediate needs of tackling air contamination and climate change are not the same for all nations in the short-run (Confalonieri et al., 2007). Alleviation of global warming and air pollutants by introducing advanced methodologies that decrease 


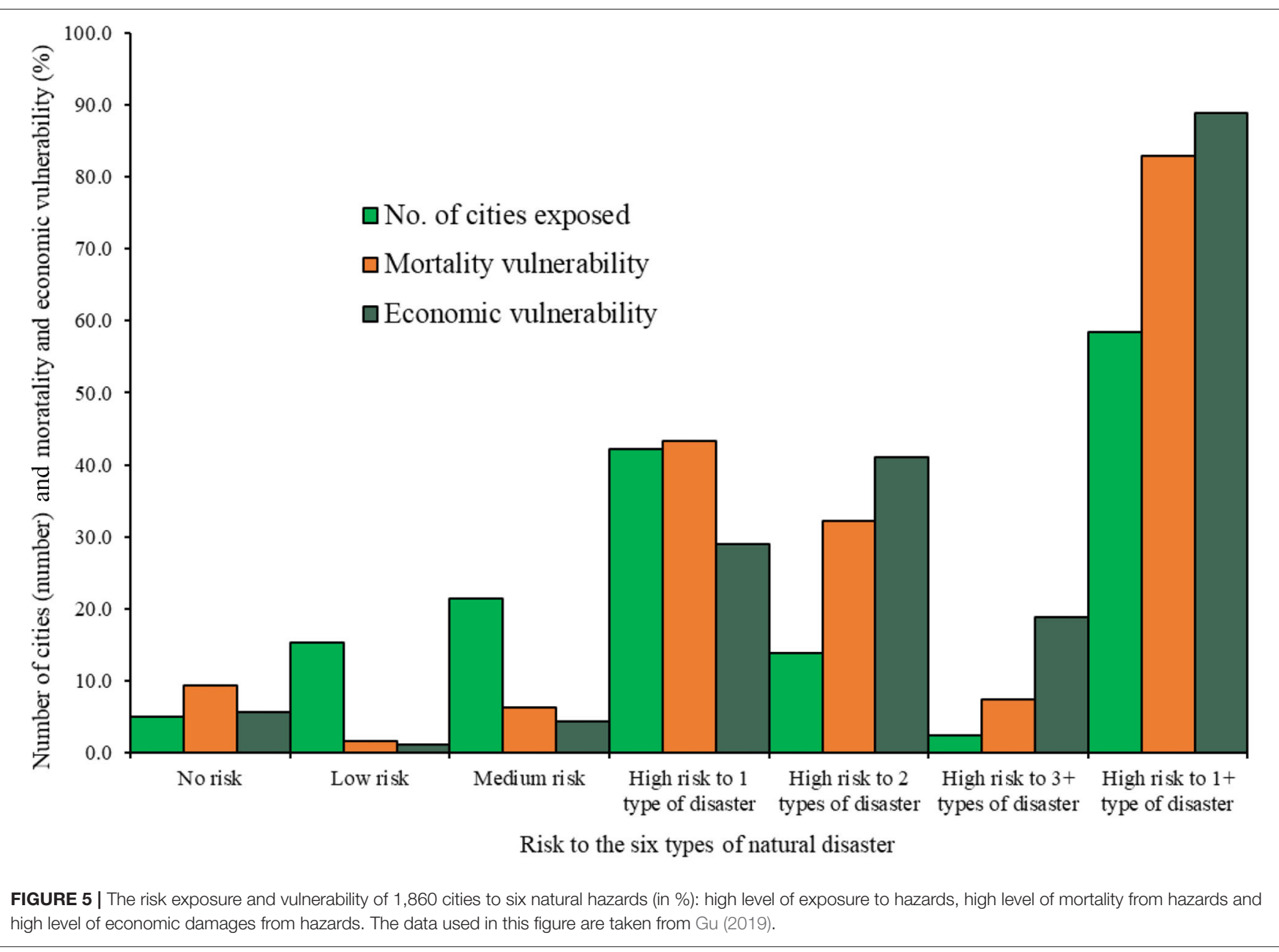

local and regional air contamination can improve human health and surroundings, and may likewise support economic growth (Patz et al., 2014). However, atmospheric aerosols (or particulate matter) and global warming are traditionally seen as two separate issues across numerous science and policy areas, despite the fact that aerosols and GHGs share multiple atmospheric properties, emission sources, and means of mitigation. This may be as a result of policy trade-offs to some degree, where amelioration of surrounding aerosols cannot profit climate change, and vice versa. However, there are various significant co-benefit strategies, such as reducing GHGs (radiative forcing) also reduces ambient aerosols (air pollution) produced from similar sources (Kumar and Saroj, 2014; Von Schneidemesser et al., 2015). Indeed, climate change and air pollution are two sides of the same coin; they share predominantly similar causes (e.g., GHGs) and mitigation measures (e.g., green infrastructures). In reality, there are numerous opportunities to mitigate and adapt to climate change and to enhance air quality. However, alleviation measures that blindly prioritize one aspect can inadvertently exacerbate manifestations of the other. The pursuit of ideal strategies for addressing both air pollution and climate change will accordingly require cautious regulation, legislation and presentation. It will also mean a level of compromise and cooperation on the two sides. Thus, coordinated global action, considering air pollutionclimate change linkages, is urgently needed.

Overall, the complex relationship between climate change and air pollution means that future policies that alleviate these dual problems will profit from better coordination. Evaluating the effects on human wellbeing of alternative policy methods to mitigate climate change and pollution will be a key area of future study. Innovative city planning initiatives that integrate the common interests of climate and health have received increasing attention. Holistic and interdisciplinary approaches, complemented by nature-inspired solutions (e.g., Kumar et al., 2020b), are required to tackle the global challenge of climate change. Active involvement of multiple stakeholders will support the sustainability and efficacy of any identified strategies. These appear to be another critical area of expanded research work in coming years. As a founding Chief Specialty Editor, I am looking ahead to forward-looking publications on these critical areas in the "Climate Change and Cities" section of the journal. 


\section{AUTHOR CONTRIBUTIONS}

The author wrote this invited Grand Challenge article in the capacity of founding Specialty Cheif Editor for the Climate Change and Cities section of the journal.

\section{FUNDING}

PK acknowledges the support received by the ASAP-Delhi (An Integrated Study of Air Pollutant Sources in the Delhi National

\section{REFERENCES}

Adger, W. N. (2006). Vulnerability. Glob. Environ. Change 16, 268-281. doi: 10.1016/j.gloenvcha.2006.02.006

Confalonieri, U., Menne, B., Akhtar, R., Ebi, K., Hauengue, M., Kovats, R., et al. (2007). Human health. Cambridge: Cambridge University Press.

Debele, S. E., Kumar, P., Sahani, J., Marti-Cardona, B., Mickovski, S. B., Leo, L. S., et al. (2019). Nature-based solutions for hydro-meteorological hazards: revised concepts, classification schemes and databases. Environ. Res. 179:108799. doi: 10.1016/j.envres.2019.108799

Du, Z., Lawrence, W. R., Zhang, W., Zhang, D., Yu, S., and Hao, Y. (2019). Interactions between climate factors and air pollution on daily HFMD cases: a time series study in Guangdong, China. Sci. Total Environ. 656, 1358-1364. doi: 10.1016/j.scitotenv.2018.11.391

Ebi, K. L., Mills, D. M., Smith, J. B., and Grambsch, A. (2006). Climate change and human health impacts in the United States: an update on the results of the US national assessment. Environ. Health Perspect. 14, 1318-1324. doi: $10.1289 /$ ehp. 8880

EEA (2017). Climate Change Impacts and Vulnerability in Europe - An Indicator-Based Report. EEA Report European Environment Agency. Available online at: https://www.eea.europa.eu/publications/climate-change-impactsand-vulnerability-2016 (accessed October 05, 2020).

EPA (2020). Greenhouse Gas Emissions, Overview of Greenhouse Gases. Available online at: https://www.epa.gov/ghgemissions/overview-greenhousegases (accessed 20 November 2020).

Gu, D. (2019). Exposure and vulnerability to natural disasters for world's cities. DESA 4, 1-43. Available online at: https:/www.un.org/en/development/ desa/population/publications/pdf/technical/TP2019-4.pdf (accessed February $5,2021)$.

Heal, M. R., Kumar, P., and Harrison, R. M. (2012). Particles, air quality, policy and health. Chem. Soc. Rev. 41, 6606-6630. doi: 10.1039/c2cs35076a

IPCC (2013). "Summary for policymakers," in Climate Change 2013: The Physical Science Basis. Contribution of Working Group I to the Fifth Assessment Report of the Intergovernmental Panel on Climate Change, Stocker, T.F., D. Qin, G.-K. Plattner, M. Tignor, S.K. Allen, J. Boschung, A. Nauels, Y. Xia, V. Bex and P.M. Midgley, eds. Cambridge, New York, NY: Cambridge University Press.

IPCC (2014). "Intergovernmental panel on climate change climate change," in Human Health-Impacts Adaption and Co-Benefits Cimate Change: Impacts, Adaption, and Vulnerability Working Group II Contribution to the IPCC 5th Assessment Report. Cambridge: Cambridge University Press (2014).

IPCC (2018). Managing the Risks of Extreme Events and Disasters to Advance Climate Change Adaptation: Special Report of the Intergovernmental Panel on Climate Change. Cambridge: Cambridge University Press. Available online at: https://www.ipcc.ch/report/managing-the-risks-of-extreme-eventsand-disasters-to-advance-climate-change-adaptation/ (accessed October 05, 2020).

Kumar, P., Adelodun, A. A., Khan, M. F., Krisnawati, H., and Garcia-Menendez, F. (2020a). Towards an improved understanding of greenhouse gas emissions and fluxes in tropical peatlands of Southeast Asia. Sustain Cities Soc. 53:101881. doi: 10.1016/j.scs.2019.101881

Kumar, P., Debele, S. E., Sahani, J., Aragão, L., Barisani, F., Basu, B., et al. (2020b). Towards an operationalisation of nature-based solutions for natural hazards. Sci. Total Environ. 731:138855. doi: 10.1016/j.scitotenv.2020. 138855
Capital Region; Grant No. NE/P016510/1) as a part of the UKIndia NERC-MOES Programme on Atmospheric Pollution and Human Health in an Indian Megacity (Delhi), OPERANDUM (OPEn-air laboRAtories for Nature baseD solUtions to Manage hydro-meteo risks; Grant Agreement No: 776848), and the Clean Air Engineering for Homes (CArE-Homes) project, which is funded by the University of Surrey's Research England funding under the Global Challenges Research Fund (GCRF) programme.

Kumar, P., and Imam, B. (2013). Footprints of air pollution and changing environment on the sustainability of built infrastructure. Sci. Total Environ. 444, 85-101. doi: 10.1016/j.scitotenv.2012.11.056

Kumar, P., and Saroj, D. P. (2014). Water-energy-pollution nexus for growing cities. Urban Climate 10, 846-853. doi: 10.1016/j.uclim.2014.07.004

Ma, Q., Qi, Y., Shan, Q., Liu, S., and He, H. (2020). Understanding the knowledge gaps between air pollution controls and health impacts including pathogen epidemic. Environ. Res. 189:109949. doi: 10.1016/j.envres.2020.10 9949

Maione, M., Fowler, D., Monks, P. S., Reis, S., Rudich, Y., Williams, M. L., et al. (2016). Air quality and climate change: designing new win-win policies for Europe. Environ. Sci. Policy 65, 48-57. doi: 10.1016/j.envsci.2016.03.011

Masselot, P., Chebana, F., Ouarda, T. B., Bélanger, D., St-Hilaire, A., and Gosselin, P. (2018). A new look at weather-related health impacts through functional regression. Sci. Rep. 8, 1-9. doi: 10.1038/s41598-018-33626-1

O'Neill, M. S., and Ebi, K. L. (2009). Temperature extremes and health: impacts of climate variability and change in the United States. J. Occup. Environ. Med. 51, 13-25. doi: 10.1097/JOM.0b013e318173e122

Patz, J. A., Frumkin, H., Holloway, T., Vimont, D. J., and Haines, A. (2014). Climate change: challenges and opportunities for global health. JAMA 312, 1565-1580. doi: 10.1001/jama.2014.13186

Rahmstorf, S., and Coumou, D. (2011). Increase of extreme events in a warming world. Proc. Natl. Acad. Sci. U.S.A.108, 17905-17909. doi: 10.1073/pnas.1101766108

Re Swiss (2020). Re Databases 9980-2018. Available online at: https://swissre.com (accessed 20 October 2020).

Rogelj, J., Den Elzen, M., Höhne, N., Fransen, T., Fekete, H., Winkler, H., et al. (2016). Paris Agreement climate proposals need a boost to keep warming well below 2C. Nature 534, 631-639. doi: 10.1038/nature18307

Schmale, J., Shindell, D., von Schneidemesser, E., Chabay, I., and Lawrence, M. (2014). Air pollution: clean up our skies. Nat. News 515:335. doi: $10.1038 / 515335 a$

Shindell, D., Borgford-Parnell, N., Brauer, M., Haines, A., Kuylenstierna, J. C. I., Leonard, S. A., et al. (2017). A climate policy pathway for nearand long-term benefits. Science 356, 493-494. doi: 10.1126/science.aak 9521

Shindell, D., Kuylenstierna, J. C., Vignati, E., van Dingenen, R., Amann, M., Klimont, Z., et al. (2012). Simultaneously mitigating near-term climate change and improving human health and food security. Science 335, 183-189. doi: $10.1126 /$ science. 1210026

Shuman, E. K. (2010). Global climate change and infectious diseases. N. Engl. J. Med. 362, 1061-1063. doi: 10.1056/NEJMp0912931

Sun, S., Tian, L., Cao, W., Lai, P. C., Wong, P. P. Y., Lee, R. S. Y., et al. (2019). Urban climate modified short-term association of air pollution with pneumonia mortality in Hong Kong. Sci. Total Environ. 646, 618-624. doi: 10.1016/j.scitotenv.2018. 07.311

Swiss Re (2020). Swiss Reinsurance Company Database (9980-2020). Available online at: https://www.swissre.com/ (accessed October 12, 2020).

UNISDR (2002). Disaster Reduction and Sustainable Development: Understanding the Links Between Vulnerability and Risk Related to Development and Environment. Geneva: United Nations International Strategy for Disaster Reduction. Available online at: https://www.gdrc.org/uem/disasters/disenvi/ DR-and-SD-English.pdf (accessed October 05, 2020). 
UNISDR (2020). Available on: https://www.unisdr.org/we/inform/terminolog (accessed 20 October 2020).

Von Schneidemesser, E., Monks, P. S., Allan, J. D., Bruhwiler, L., Forster, P., Fowler, D., et al. (2015). Chemistry and the linkages between air quality and climate change. Chem. Rev. 115, 3856-3897. doi: 10.1021/acs.chemrev.5b00089

Watts, N., Adger, W. N., Agnolucci, P., Blackstock, J., Byass, P., Cai, W., et al. (2015). Health and climate change: policy responses to protect public health. Lancet 386, 1861-1914. doi: 10.1016/S0140-6736(15)6 0854-6

WHO (2014). Quantitative Risk Assessment of the Effects of Climate Change on Selected Causes of Death, 2030s and 2050s. World Health Organization. Available online at: https://www.who.int/globalchange/publications/ quantitative-risk-assessment/en/ (accessed 23 November 2020).

Williams, M. (2012). Tackling climate change: what is the impact on air pollution? Carbon Manag. 3, 511-519. doi: 10.4155/cmt.12.49

$\mathrm{Xu}, \mathrm{Y}$., and Lamarque, J. F. (2018). Isolating the meteorological impact of 21 st century GHG warming on the removal and atmospheric loading of anthropogenic fine particulate matter pollution at global scale. Earth Future 6, 428-440. doi: 10.1002/2017EF00 0684

Yao, L. (2017). Causative impact of air pollution on evapotranspiration in the North China Plain. Environ. Res. 158, 436-442. doi: 10.1016/j.envres.2017. 07.007

Conflict of Interest: The author declares that the research was conducted in the absence of any commercial or financial relationships that could be construed as a potential conflict of interest.

The handling editor declared a past co-authorship with the author PK.

Copyright (C) 2021 Kumar. This is an open-access article distributed under the terms of the Creative Commons Attribution License (CC BY). The use, distribution or reproduction in other forums is permitted, provided the original author(s) and the copyright owner(s) are credited and that the original publication in this journal is cited, in accordance with accepted academic practice. No use, distribution or reproduction is permitted which does not comply with these terms. 